\title{
Sand and Dust Storms (SDS): Types, Characteristics, and Indications
}

\author{
Ali Al-Dousari ${ }^{1}{ }^{*}$, Ali Al Hamoud ${ }^{1}$, Modi Ahmed ${ }^{1}$ and Noor Al-Dousari ${ }^{1}$ \\ ${ }^{1}$ Kuwait Institute for Scientific Research (KISR), Environmental and Life Sciences Research Center (ELSRC)
}

\begin{abstract}
Sand and dust storms (SDS) is a common weather phenomenon in the Middle East. Topography and the northern or northwesterly wind are the main control factors for types of SDS trajectories. The main SDS corridors in the Middle East were classified and spotted from March 2000 to March 2017. The SDS can be classified in the region in accordance to shape and magnitude into three main types namely; Small with 3 subtypes (Arrow shape-straight, Arrow shape-curved and Needle like), Intermediate with 3 subtypes (Curved, Hook and Straight), and Extensive with 6 subtypes (Spiral, Agglomerated-Dense, AgglomeratedDispersed, Wavy, Hook-Single head, and Hook-multiple heads). Most of the trajectories are located within the northeastern parts of the Middle East. Dust properties led us to sort SDS and their indications. Dust deposits in the eastern Mediterranean Sea and the Red Sea and are initiated from Northern Desert of Africa (NDA). On the other hand, dust deposits in the Middle East originate from NDA, Western Desert of Iraq (WD), Mesopotamian Flood Plain (MFP), Ahwaz (HZ), Ahwar (HR) and Baluchistan Desert (BSH). The deposited dust in coastal areas is categorized as trimodal particle size distribution, finer mean size fractions with higher values of particles surface area and contains more carbonates and less quartz percentages compared to fallen dust in inland regions which is dominantly initiated from Western Desert of Iraq (WD), Nafud Desert (NFD) and Empty Quarter (EQ).
\end{abstract}

\section{Introduction}

Sand and dust storms (SDS) are a common phenomena in the Middle East region $[1,2]$. The Middle East region is surrounded by a desert ecosystem characterized by active aeolian conditions [3-5]. The SDS has a huge socioeconomic effect mainly on the marine environment $[6,7]$, human health [8], aviation and oil industry $[9,10]$. The SDS passing over the region are considered to be major sources of sediments [11-14]. Al-Dousari [1] found evidence of local, regional and global sources contribution to dust throw in higher percentages of sand particles within dust contents. Globally, there is a need to put proper classification for SDS trajectories, and it is indications. Therefore, this study aims to pass through the relation between climate and dust within the Middle East region.

\section{Materials and methods}

SDS was monitored using images of from MODIS (The moderate-resolution imaging spectroradiometer) within the period from 2002 to 2017 taking in consideration the meteorological data in the region. Deposited dust was also collected from smooth surfaces on buildings with $5 \mathrm{~m}$ at least above ground level roofs in Cairo-Egypt, Manama-Bahrain, Riyadh and Walamen-south Arabia, south Ahwar-Iraq, and Dubai and Ain-UAE. The collected samples were analyzed by scanning electron microscope (SEM), and the Brunauer, Emmett, and Teller (BET) particles surface area, Centrifugal Particle Analyzer (using Friedman and Blott methods [16]) and $\mathrm{X}$-ray diffraction (XRD).

\section{Results and discussion}

The SDS was categorized into three major forms in accordance to their size: Small (SDS width less than 100 $\mathrm{km}$ ), Intermediate (width 100-300 km) and Extensive (width more than $300 \mathrm{~km}$ ).

Among the three major types, there are 12 subtypes of SDS trajectories (Fig. 1). The wide SDS dominantly originated at the northern part of the Arabian Peninsula and normally originated from Nafud Desert (NFD), East Syria and south Turkey, the Mesopotamian Flood Plain (MFP), Western Desert of Iraq (WD) and the Ahwaz (HZ) or by the combination between multiple sources and each path has it is own fingerprint in the dust properties (Fig. 2). The wide SDS dominantly originated at the southern part is majorly from the Empty Quarter desert (EQ).

The very fine and fine sand particles represent $58 \%$ of the average dust fallout percentages in desert areas, while they represents only $11 \%$ within the coastal area of the Middle East. The dust fallout particles are fining towards the coastal regions within the Middle East and getting coarser towards the desert areas (Table 1). Quartz and carbonates are the major components of dust in the

Corresponding author: adousari@kisr.edu.kw 
region, feldspars are found with certain percentages, but it was observed that quartz increases and carbonates decrease in the desert area dust. Evaporites (anhydrite, gypsum, and Bassanite) and heavy minerals are present with minor percentages in the dust (Fig. 3, Table 2). The coastal dust shows much more BET-surface area for partcles compared to the desert dust in Kuwait and in the globe (Fig. 4).
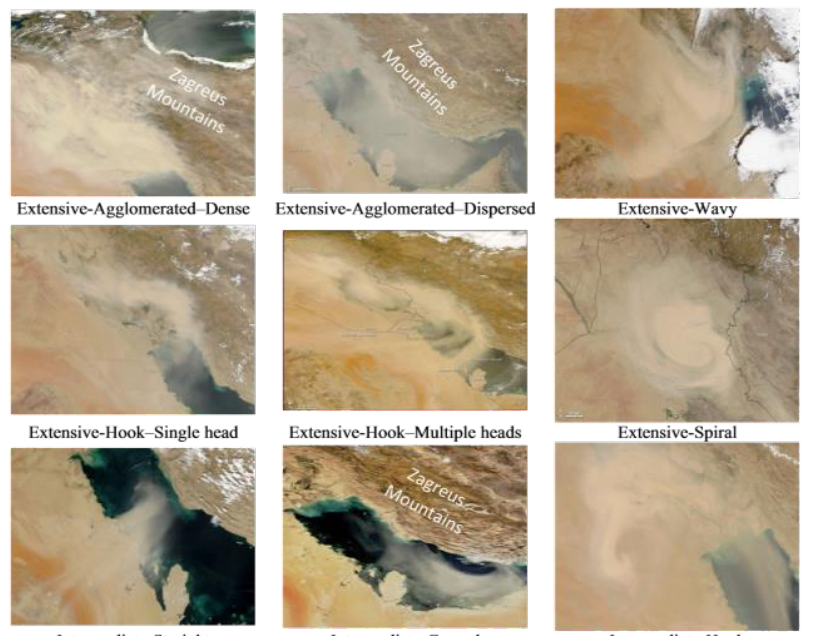

Intermediate-Straight
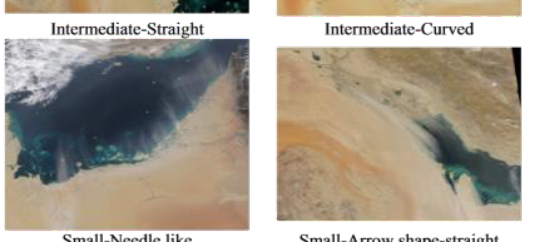

Small-Arrow shape-straight
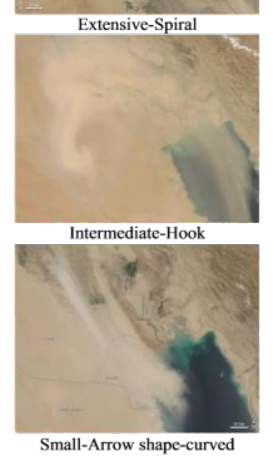

Fig. 1. Sorting index of sand and dust storms (SDS) observed by MODIS images (3 major types and 12 sub types) [3].

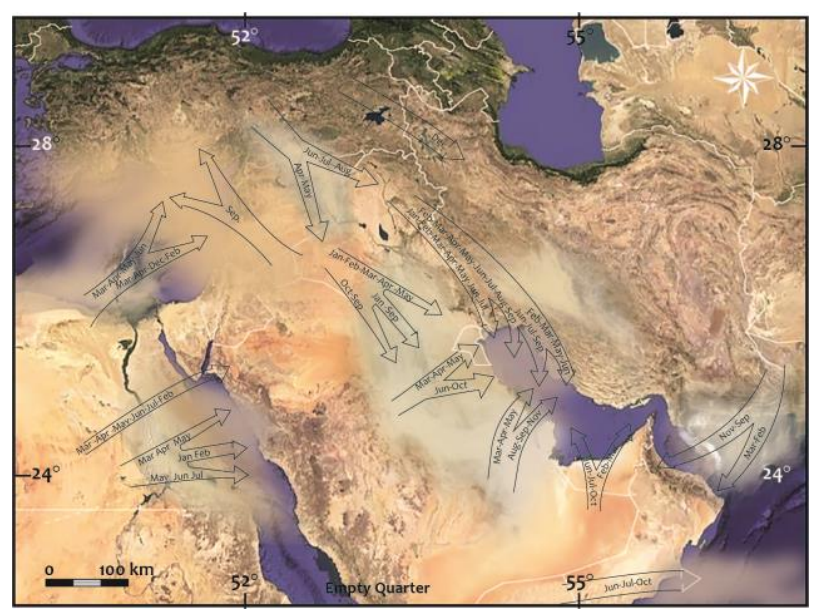

Fig. 2. Temporal and spatial dispersal for numerous dominant SDS main trajectories (2000-2017) overlaid images in the Middle East.

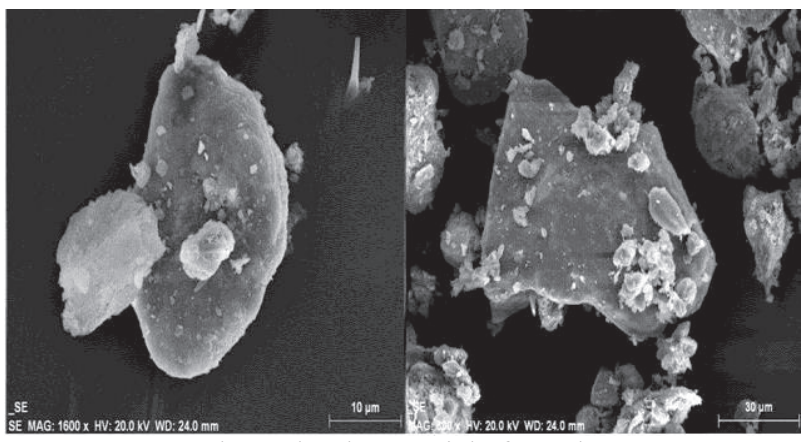

Fig. 3. Quartz subangular dust particle from the Empty Quarter carrying tiny particles of carbonates and feldspars (left), carbonates and evaporites as adhering particles on the surface of quartz from Buibiyan Island in Kuwait (right).

Table 1. Particle size percentages of dust fallout within world major dust storm trajectories [17].

\begin{tabular}{|l|c|c|c|c|c|c|c|}
\hline \multirow{2}{*}{\multicolumn{1}{c|}{ Location }} & A & C & C & D & E & F & G \\
\cline { 2 - 8 } & 37 & 22 & 18 & 14 & 7 & 2 & 0 \\
\hline $\begin{array}{l}\text { Kalamen- } \\
\text { Saudi }\end{array}$ & 40 & 8 & 21 & 15 & 11 & 2 & 4 \\
\hline Ain & 97 & 0 & 1 & 1 & 1 & 1 & 0 \\
\hline Dubai & 17 & 3 & 14 & 24 & 23 & 10 & 8 \\
\hline Amman-Jordan & 30 & 11 & 30 & 17 & 8 & 2 & 2 \\
\hline Um Qasir-Iraq & 3 & 12 & 20 & 25 & 15 & 5 & 20 \\
\hline $\begin{array}{l}\text { Manamah- } \\
\text { Bahrain }\end{array}$ & 12 & 10 & 20 & 11 & 13 & 5 & 28 \\
\hline Tripoli-Libya & 20 & 12 & 17 & 19 & 17 & 8 & 8 \\
\hline $\begin{array}{l}\text { Biougra- } \\
\text { Morocco }\end{array}$ & 12 & 28 & 22 & 16 & 8 & 8 & 6 \\
\hline $\begin{array}{l}\text { Cartagena- } \\
\text { Colombia }\end{array}$ & 10 & 4 & 18 & 22 & 18 & 12 & 16 \\
\hline Arizona-USA & 9 & 26 & 30 & 13 & 8 & 4 & 10 \\
\hline Tripoli-Libya & 20 & 12 & 17 & 19 & 17 & 8 & 8 \\
\hline Cairo-Egypt & 10 & 15 & 37 & 21 & 10 & 4 & 3 \\
\hline $\begin{array}{l}\text { Taklimakan- } \\
\text { China }\end{array}$ & 70 & 24 & 2 & 1 & 2 & 1 & 0 \\
\hline Ejin-China & 35 & 18 & 10 & 8 & 5 & 2 & 22 \\
\hline Siberia-Russia & 11 & 31 & 28 & 11 & 7 & 4 & 8 \\
\hline $\begin{array}{l}\text { Bald Hill- } \\
\text { Australia }\end{array}$ & 9 & 3 & 5 & 5 & 4 & 3 & 70 \\
\hline Average & 26 & 14 & 18 & 14 & 10 & 5 & 13 \\
\hline Max & 97 & 31 & 37 & 25 & 23 & 12 & 70 \\
\hline Min & 3 & 0 & 1 & 1 & 1 & 1 & 0 \\
\hline Where A: & B: Verticle size percentages \\
\hline
\end{tabular}

Where A: sand, B: Very coarse silt, C: coarse silt, D: medium silt, E: fine silt, F: very fine silt, and G: clay.

\section{Summary and conclusions}

The Middle East SDS trajectories (2000-2017) were detected and categorized using satellite images and weather data. The coastal dust regions in the Arabian Gulf, Red Sea, and Mediterranian Sea contain more carbonates and finner in size fraction. The finning of 
dust towards the coastal region can be attributed to the presence of the water bodies as they act as a dust trap mainly for larger particles. Knowledge about properties of dust in the region is so valuable in socioeconomically, mainly for future urbanization, solar energy units, and health aspects.

Table 2. Depositional rates of dust fallout within major dust storm trajectories in the world [17].

\begin{tabular}{|c|c|c|c|c|c|c|c|}
\hline Location & $\mathbf{A}$ & B & C & D & $\mathbf{E}$ & $\mathbf{F}$ & G \\
\hline Kuwait & 38 & 38 & 7 & 45 & 10 & 2 & 5 \\
\hline Um Qasir-Iraq & 13 & 78 & 3 & 80 & 8 & 0 & 0 \\
\hline Riyadh-Saudi & $\underline{68}$ & $\underline{32}$ & $\underline{0}$ & $\underline{32}$ & $\underline{0}$ & $\underline{0}$ & $\underline{0}$ \\
\hline Walamen-Saudi & 62 & 13 & 0 & 13 & 24 & 1 & 0 \\
\hline Ain-UAE & 26 & 34 & 19 & 52 & 20 & 1 & 0 \\
\hline Dubai-UAE & 21 & 25 & 21 & 45 & 6 & 0 & 27 \\
\hline Amman-Jordan & 21 & 52 & 16 & 68 & 4 & 0 & 7 \\
\hline $\begin{array}{l}\text { Manama- } \\
\text { Bahrain }\end{array}$ & 32 & 25 & 16 & 41 & 10 & 3 & 15 \\
\hline Tropoli-Libya & 64 & 27 & 0 & 27 & 5 & 4 & 0 \\
\hline $\begin{array}{l}\text { Sosmasa- } \\
\text { Morocco }\end{array}$ & 46 & 46 & 0 & 46 & 8 & 1 & 0 \\
\hline Bawku-Ghana & 87 & 0 & 0 & 0 & 9 & 2 & 2 \\
\hline $\begin{array}{l}\text { Cartagena- } \\
\text { Colombia }\end{array}$ & 66 & 0 & 0 & 0 & 33 & 0 & 1 \\
\hline Cairo-Egypt & 51 & 20 & 14 & 34 & 15 & 0 & 0 \\
\hline Negev-Palestine & 41 & 21 & 2 & 23 & 18 & 17 & 0 \\
\hline Shapotou-China & 38 & 28 & 0 & 28 & 21 & 7 & 5 \\
\hline Beijing-China & 24 & 9 & 0 & 9 & 13 & 51 & 3 \\
\hline Andong-S Korea & 28 & 8 & 0 & 8 & 19 & 45 & 0 \\
\hline $\begin{array}{l}\text { Bald Hill- } \\
\text { Australia } \\
\end{array}$ & 57 & 0 & 0 & 0 & 21 & 14 & 7 \\
\hline Average & 44 & 24 & 5 & 29 & 13 & 10 & 4 \\
\hline Maximum & 87 & 78 & 21 & 80 & 33 & 51 & 27 \\
\hline Minimum & 13 & 0 & 0 & 0 & 0 & 0 & 0 \\
\hline
\end{tabular}

Where A: quartz, B: calcite, C: dolomite, D: carbonates, $\mathrm{E}$ : clay, and F: other minerals.

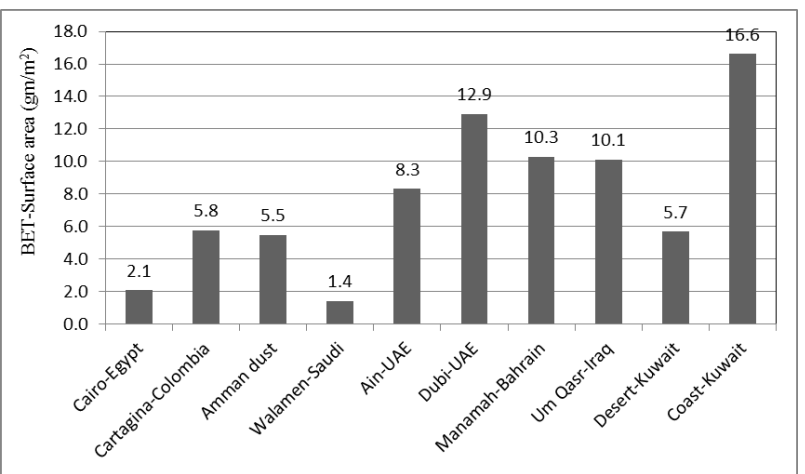

Fig. 4. The BET surface area of dust samples in comparison to surface sediments and other aeolian samples in the world.
This work was funded by the Kuwait Institute for Scientific Research (KISR) and Kuwait Foundation for the Advancement of Science (KFAS) grant number (2008-1401-01).

\section{References}

1. A.M. Al-Dousari, A. Al-Hazza. Arabian J. Geosci. 6(2), 519-527. (2013)

2. J.M. Al-Awadhi, A.M. Al-Dousari, F.I. Khalaf. Atmos. Climate Sci. 4, 437-446, (2014)

3. A. Al-Dousari, D. Doronzo, M. Ahmed. Sustainability. 9(9), 1526. (2017)

4. I. Sabbah, J.F. Léon, M. Sorribas, B. Guinot, C. Córdoba-Jabonero, A. De Souza, F. Al Sharifi. J. Atmos. Solar-Terrestrial Phys. 179, 105-113. (2018)

5. A.M. Al-Dousari, K. Pye. Kuwait Journal of Science and Engineering. 32(2), 119-134. (2005).

6. A.M. Al-Dousari, A. Al-Enezi, J. Al-Awadhi. Arabian J. Geosci. 1(1), 17-31. (2008)

7. E. Al-Enezi, A.M. Al-Dousari, T. Pokavanich, F.M. Al-Shammari. J. Eng. Res. 2(2),1-14. (2014)

8. A.M Al-Dousari, M.I. Ibrahim, N. Al-Dousari, M. Ahmed, S. Al-Awadhi. Aerobiologia. 34(3), 325336, (2018)

9. A. Al-Hemoud, M. Al-Sudairawi, S. Neelamanai, A. Naseeb, W. Behbehani. Arabian J. Geosci. 10(1), 18. (2017)

10. A. Al-Hemoud, A. Al-Dousari, A. Al-Shatti, A. AlKhayat, W. Behbehani, M. Malak. Atmos. 9(1), 6. (2018)

11. J.M. Al-Awadhi, A.M. Al-Dousari. International Journal of Earth Sciences. 102(3), 949-958, (2013)

12. A. Al-Dousari. Arab Gulf Journal of Scientific Research. 23(2), 69-79. (2005)

13. J.M. Al-Awadhi, A. Al-Dousari, A. Al-Enezi,. Arab Gulf Journal of Scientific Research. 18(1), 32-40. (2000)

14. J.M. Al-Awadhi, A.M. Al-Dousari. International Journal of Earth Sciences. 102(3), 949-958, (2013)

15. G.M. Friedman, J.A. Sanders. Principle of Sedimentology. Journal of Earth New York, Wiley. (1978)

16. S. Blott, A.M. Al-Dousari K. Pye, S Saye. J Sed. Res. 74(1): 156-159, (2004)

17. A. Al-Dousari, J. Al-Awadhi, M. Ahmed. Arabian J. Geosci. 6(10), 3877-3884. (2013) 